Kalapos Miklós Péter

\title{
Néhány gondolat a kábítószer-problémás egyének önkéntes eltereléséről orvosi szemmel
}

Some thoughts about the voluntary admission to treatment as an alternative for punishment for drug using individuals from a medical point of view

\begin{abstract}
Absztrakt
A dolgozat a büntetés helyett a kezeléselv (elterelés) egy speciális szegmensének, az úgynevezett önként vállalt elterelésnek a jövendő kezelés szempontjából - két esetet részleteiben is bemutatva - tekinti át az eljáró hatóság és az egészségügyi szolgáltatók eltérő hozzáállásának negatív terápiás hatásait. Az elterelés jogi fogalom, de végrehajtása gyakran az egészségügyi ellátók feladata, ezért az ő szempontjaik figyelembevétele fontos. Orvosi szempontból kritikus elem az önkéntes elterelést illetően többek között, és különösen, a különböző addikciós hátterü kliensek ellátási igény szerinti differenciálásának, illetve a kezelés tartalmának egyértelmü, az egészségügyi igényekhez illeszkedő protokollszintű meghatározásának hiánya, és kiemelten az elterelésre kötelezettek csekély motivációja. Ezért sem közömbös, hogy a hatósági eljárás mennyire szakszerü és milyen reakciókat vált ki a kliensből. E tekintetben a hatósági munka meglehetős egyenetlenségeket mutat. Ezért a tanulmány felveti annak igényét, hogy az önként vállalt elterelés elindításához jól dokumentált hatósági határozatra legyen szükség.
\end{abstract}

Kulcsszavak: büntetés helyett kezelés, elterelés, kémiai szerhasználat, Büntető Törvénykönyv, motiváció

\section{Abstract}

The article reviews the negative effects of different attitudes of the enforcing authorities and the healthcare providers in the therapy of a special segment of treatment instead of punishment process (diversion) -including a detailed presentation of two cases. This segment is the so-called voluntary diversion. Diversion is a legal concept, but its implementation is often the task of health care providers, therefore it is important to consider their aspects, too. From medi- 
cal point of view the voluntary diversion suffers, among others, from the lack of distinction of clients with different addictive backgrounds, of clear protocol-based definition of treatment, and especially of the low motivation of clients. Therefore, it is not negligible to know how professional the official procedure is and what reactions it actuates in the client, either increasing or diminishing the motivation. In this respect, the work of authorities is quite unbalanced. Therefore, the article raises the need of a well-documented official decision to start voluntary diversion.

Keywords: treatment instead of punishment, diversion, chemical substance use, Criminal Code, motivation

\section{Bevezetés}

A Büntető Törvénykönyv (Btk) 1993. évi módosításával (1993. évi XVII. törvény a büntető jogszabályok módosításáról) az elterelés intézménye (büntetés helyett kezelés elve) megjelent a magyar igazságszolgáltatás eszköztárában. Az idézett törvény 61 . § értelmében a Btk. a következő 282/A. §-sal egészült ki:

„,282/A. § Nem büntethetö, aki a) csekély mennyiségü kábitószert saját használatára termeszt, állit elö, megszerez vagy tart; b) kábitószer fogyasztásával összefüggö - kétévi szabadságvesztésnél nem súlyosabban büntetendö - büncselekményt követett el; feltéve, hogy az elsöfokú itélet meghozataláig okirattal igazolja, hogy legalább hat hónapig folyamatos, kábitószerfüggőséget megelözö vagy gyógyitó kezelésben részesült."

Ezzel az aktussal a jogalkotó korszakos lépést tett a kábítószerekkel ${ }^{1}$ kapcsolatos jogi kérdések kezelésében, mert a magyar büntető jogalkotás történetében először került sor a keresleti, fogyasztói és a kínálati oldal szétválasztására. Míg az utóbbi esetében a szabályokat szigorították, addig a fogyasztók - bizonyos feltételek teljesülése esetében - mentesülhettek magatartásuk büntetőjogi következményei alól. Ezek a feltételek tették lehetővé, hogy a kábítószer-problémás illetőt (a szerfüggőt és az alkalmi használót egyaránt) a büntetőjogi eljárás felől az egészségügyi kezelés, illetve a felvilágosítás irányába tereljék. Mindez jól

1 2012. évi C. törvény 180. § (1) „Nem büntethető, aki csekély mennyiségü kábitószert saját használatra termeszt, eloaallit, megszerez vagy tart, illetve a ki kábitoszert fogyaszt, ha a büncselekmény elkövetését beismeri, es az elsöfokú ügydöntó hatarozat meghozatalaig okirattal igazolja, hogy legalább hat hónapig folyamatos, kábitoszer-függóséget gyogyito kezelésben, kảbitószer-használatot kezelö más ellátásban részesült, vagy megelözó-felvilágositó szolgáltatáson vett részt. illeszkedett a forenzikus (bünügyi) pszichiátria diversion from custody vonulatába is (Birmingham, 2001) és egy lépés volt a dekriminalizáció irányába. A büntetés helyett kezelés a jogi gondolkodás megváltozásának eredménye, egyfajta kompromisszumot ajánl. Sok országban általános gyakorlattá vált, jóllehet annak tartalma országonként eltérő. (Rácz, 2005; Lévay, 2006)

A köznyelv a kábítószerek körébe a más viselkedési állapot kiváltására alkalmas, illegálisan beszerezhető szereket sorolja. A gyógyszereket és az alkoholt sem a köznyelv, sem pedig a hatályos jogszabályok nem ebbe a kategóriába sorolják. A tanulmányban ezt az elnevezést használjuk, ám valójában a tudatmódosító biológiai hatással rendelkező, függőséget okozó kémiai szerek lenne a pontos, bár kissé hosszú megfogalmazás, mert ez a megfogalmazás ezen anyagok természetét és klinikai jelentőségét precízen és a lényeget megragadóan írja le. (Kalapos, 2016)

Bár az elterelés hazai szakirodalma nem túl bőséges, de áttekintő tanulmányok, illetve az elterelés hatásosságát vizsgáló dolgozatok hozzáférhetők, jóllehet megközelítésük alapvetően eltérő indíttatású. (Csorba, 2000; Ritter, 2003; Rácz, 2005; Melles és tsai., 2008; Medveczky, 2009; Vitray és tsai., 2010; Kalapos, 2011)

Jelen tanulmányban a büntetés helyett kezelés (röviden elterelés) intézményének egy szegmensére, az önkéntes elterelésre, illetve annak visszásságaira fókuszálunk, és az elterelés orvosi, illetve egyéb aspektusainak tárgyalásától eltekintünk. A gyakorló orvos szemszögéből irányítjuk rá a figyelmet a jogalkalmazás terápiát negatívan befolyásoló problémáira.

\section{Esetismertetés}

A kérdéskör vizsgálata különösen indokolt, mert gyakran fiatalkorú vagy fiatal személyekről van szó, és a jelenség független az éppen hatályos elterelésre vonatkozó jogszabályoktól, sokkal inkább az eljáró hatóságok hozzáállásáról szól. Ezért az orvos problémáinak bemutatására két esetet ismertetünk - két, az addiktológiai problémák természete szempontjából eltérő felfogású kormányzat regnálása idejéböl. Ez a két eset azonban állatorvosi lóként az összes, az orvos munkáját megnehezítő tényezőt láttatja.

\section{1. eset}

Az elterelésre, a jelentkezésekor (2004) a 17. életévét még be nem töltött fiú, édesanyja kíséretében jelentkezik. Az ügyészi határozatból a cselekményről 
csak annyi derült ki, hogy egy évvel korábban (még be nem töltött 16. életév) a probandus meg nem határozott helyen két alkalommal marihuánás cigarettát fogyasztott. A szakértői vizsgálat során vizsgált vizeletből kábítószert, vagy annak származékát kimutatni nem tudtak. Az elterelésre kötelezett felvételekor elmondja, hogy a közterületen történt rendőri igazoltatáskor megemlítette, hogy ő már kipróbálta a marihuánát, és így indult ellene az eljárás. A vizsgált személy pszichiátriailag terhelt családból származik, 11 évvel idősebb bátyja skizofréniában szenved és emiatt le is százalékolták. Három évvel idősebb nővére kevert szorongásos-depresszív zavar miatt áll orvosi kezelés alatt. A négy-, illetve öttagú család, mert legtöbbször a nagymama is ott lakik, szoba-konyhás lakásban él, a súlyosan beteg báty külön él. Az elterelésre kötelezett kissúlyú koraszülött volt, de pszichiátriai kezelésben korábban nem részesült. A pszichológiai vizsgálat szerint visszahúzódó, elzárkózó, nyomott hangulatú, a normalitás képét görcsösen megőrizni törekvő serdülő, aki a belső feszültségeit elfojtja, amelyek pszichoszomatikus tünetekben vagy nonkonformis viselkedésben jutnak kifejezésre. Az eltereléssel együttmüködött, azt befejezte.

\section{2. eset}

Az elterelésre jelentkezésekor (2018) a 17. életévét még be nem töltött fiú édesanyja kíséretében jelentkezik. A rendőrségi határozatból a cselekményről csak annyi derült ki, hogy a jelentkezés évének szeptemberében a probandust az utcán hatósági intézkedés alá vonták, mert idegesen, zavarosan viselkedett. Előállítás után vizeletvételre került sor, illetve a nála megtalált kábítószergyanús anyagmaradványt igazságügyi vegyészszakértői vizsgálatra küldték. A vizeletvizsgálat eredménye nem ismert, a vegyészszakértői vélemény szerint a maradványban etil-hexadron volt kimutatható. Ez egy pszichoaktív anyag, így alkalmas lett volna Btk.-ba ütköző cselekmény megvalósítására, de tekintettel arra, hogy az elkövetett cselekmény nem büncselekmény - a Magyarországon megjelent Kábítószer és Kábítószer-függőség Európai Megfigyelő Központjának Korai Jelzőrendszerébe (EMCDDA EWS) 2005 óta bejelentett ellenőrzött anyagok büntetőjogi vonatkozású besorolása listáján nem szerepel -, ezért a nyomozást megszüntették. A pszichológiai vizsgálat szerint az elterelésre kötelezett szellemi kora egy kilenc éves gyermek életkorának felel meg, gyakorlatilag funkcionális analfabéta, írni, olvasni nem tud, önálló, felelősségteljes életvezetésre, döntésekre csak korlátozottan alkalmas.

\section{Az eljárással kapcsolatban felmerülő kérdések a terápia szempontjából}

A kérdések felvetése talán eretnek gondolatnak tủnik, de az elterelés három formája közül kettő - kábítószer-függőséget gyógyító kezelés és a kábítószer-használatot kezelő más ellátás - kötelező módon az egészségügyi rendszerhez delegált ellátás. Ennek alapján érdemes a kérdést, a hatóságok e témában mutatott tevékenységét orvosi szempontból, vagyis a későbbi terápia szempontjából is górcső alá venni. Az orvosi paradigma alaptézise, hogy az orvosi müködés célja a betegség diagnosztizálását követő terápia, amely a beteg gyógyulását, vagy legalább is életvezetési kompetenciájának javulását eredményezi. (Kalapos, 2016) Ehhez azonban gyakran kapcsolódik a betegségek kialakulását megakadályozni hivatott orvosi ténykedés is, vagyis a prevenció. Ám valójában a terápia is egyfajta megelőző orvosi ténykedés, harmadlagos prevenció. (Kalapos, 2016) Az eltereléssel kapcsolatban azonban a valóság az, hogy az esetek nem elhanyagolható részében semmiféle diagnózis felállítására nincs szükség, hiszen az illető alkalmi használó csupán. Ebben az esetben a klienst a felvilágosító-megelőző szolgáltatás felé irányítjuk, ami azonban, miként maga az egész elterelés, prevenciós beavatkozásnak minősül.

Az egészségügy kompetenciakörébe tartozó esetekben végzett elterelés során az első kérdés a kezelés szükségszerüsége. Ideális helyzetben a beteg célja azonos az orvoséval, vagyis a gyógyulás, és az orvos-beteg találkozást is rendszerint ő kezdeményezi, mert életében jelen van egyfajta egészség/betegség irányú szenvedésnyomás. Pszichológiai értelemben a motiváció a cselekvés mozgatórugója és szelektív, mivel adott időben nem akármilyen, hanem egy adott tevékenységi forma dominál. A hiányállapot megélése, a szükséglet a hiány megszüntetésére késztet. Egészségügyi kontextusban szükséglet lehet például az egészség hiányának, a betegségnek a megszüntetésére törekvés. Ám az elterelés vonatkozásában az esetek nem elhanyagolható hányadában sem az orvos, sem pedig a beteg célja nem írható le egészségügyi kategóriákkal. A klinikus számára idegen a helyzet, még ha nem is teljesen szokatlan, és már maga ez is bizonytalanságot jelent. A beteg részéről pedig a kezelés szükségszerüsége az esetek döntő részében fel sem merül. Tehát az eltereléssel kapcsolatosan a legjelentősebb problémát a kliens motiválatlansága jelenti, hiszen a kezelés keresését nem drogproblémájának belátása és annak megoldására törekvés, vagyis a kezelés szükségességének felismerése vezeti, hanem egy jogi procedúra, amely az esetleges büntetés elkerülésének lehetőségét, mintegy harmadlagos betegségelőnyként jeleníti meg a számára. (Vitrai és tsai., 2010; Kalapos, 2011; Kalapos, 2016) E konstellációban a motiváció az egyébként 
törvény által üldözendő cselekményre kiszabható büntetés elkerülésében, nem pedig az egészséget veszélyeztető magatartással történő szakításban ragadható meg. A fentiekből következően az elterelés során kezelésbe kerülő kliensekkel való munka alapját a motivációs háttér feltárása kell vagy kellene, hogy jelentse. (Rácz, 2005; Kalapos, 2011)

Már a fent leírtakból is világos, az orvos-beteg kommunikációs tér a szokásostól eltér, így a kliens nagyfokú motiválatlanságára kell számítani. Emellett a kábítószer-problémásokra jellemző alappozíció az egészségügyi ellátókkal szembeni bizalmatlanság és elutasítás, ami megnehezíti az ellátást. A hiányos motivációt, illetve a bizalmatlanságot tovább tudja csökkenteni, illetve növelni a hatóság nem átlátható munkája.

A fentiek elörebocsátása után a motivációra kifejtett hatás tekintetében vizsgáljuk meg a két esetet. Az első eset kapcsán felmerül, hogy közterületen milyen okból került sor a később elterelésre kötelezett rendőri ellenőrzésére? Továbbá a saját vallomásán túl mi támasztotta alá az illegális kémiai szerhasználatot, illetve, hogy jelen volt-e a szülő vagy jogi képviselő a kihallgatáson? E kérdések a terápiás munka szempontjából fontosak, mert az, amit a beteg mond, a történetnek csak az egyik oldalát jelenti. Ám, ha az elkövetés és a kihallgatás körülményei nincsenek világosan dokumentálva, akkor ez a verzió az egyetlen ismert olvasat a terapeuta számára, és joggal ébreszthet kétségeket még akár őbenne is. Ez a bizonytalanság nem csupán gyengíti a kliens motivációját - ami, miként bemutattuk, amúgy is hiányzik vagy gyenge -, ezáltal befolyásolva az együttmüködést, hanem lehetőséget adhat a kezelt személynek arra is, hogy önmagát egy igazságtalan eljárás áldozatának tüntesse fel, és ezáltal gellert ad a terápiának. Ami így esetleg nem a szerhasználatról, a páciens szerepéről és a kilábalás lehetőségeiről szól majd, hanem egyfajta hatóságellenes hangulatot generálva a terapeutát igyekszik az eljárással kapcsolatos állásfoglalásra kényszeríteni. És bár ez utóbbit egy tapasztalt ellátó ki tudja kerülni, de a terápiás kapcsolat szempontjából a helyzet mindenképp feszültséget képes generálni. A második eset kapcsán - az első eset tárgyalásakor már említett kérdések mellett - felmerül továbbá, hogy lényegében egy vélelem alapján küldik a klienst elterelésre (a szakértői vizsgálat nem támasztotta alá a gyanút a tekintetben, hogy illegális szert birtokolt). Ugyanakkor alapos kételyek merülnek fel a gyanúsított beszámítási képessége vonatkozásában, amelynek hiánya, vagy csökkent volta a büntethetőséget kizáró, illetve a büntetés mértékét akár korlátlanul is enyhítő körülmény. A Btk. 17. § (1) a fogalom meghatározására negatív definíciót ad, vagyis ,nem büntethetö, aki a büntetendö cselekményt az elmemüködés olyan kóros állapotában követi el, amely képtelenné teszi cselekménye következményeinek a felismerésére, vagy arra, hogy e felismerésnek megfelelöen cselekedjen". A beszámítási képesség így magába foglalja a felismerési és az akarati képességet. A felismerési képesség vizsgálatakor a kérdés az, hogy a vizsgálat alá vont személy felismerhette-e a cselekmény következményeit és annak társadalmi veszélyét, míg az akarati képesség vizsgálatakor a kérdés az, hogy az illető képes volt-e az akarat kialakítására és annak megfelelő cselekvésre. A Btk. 18. § szerint azonban alapvető követelmény, hogy a beszámítási képesség csökkenése akarattól függetlenül következzen be, vagyis azon egyének esetében a Btk. 17. § rendelkezései nem alkalmazhatók, akik önhibájukból kerültek ittas vagy bódult állapotba.

Ugyanakkor a cselekvőképesség tekintetében is felmerülhetnek kételyek. Nem csupán amiatt, hogy az elkövető kiskorú, hanem amiatt is, hogy az elterelésre kötelezett szellemi kora egy kilenc éves gyermekének megfelelö, gyakorlatilag funkcionális analfabéta és az önálló, felelősségteljes életvezetésre, döntésekre csak korlátozottan - ha egyáltalán (!) - alkalmas. Tehát az ügyei viteléhez szükséges belátási képessége - szellemi fogyatkozása miatt - tartósan és nagymértékben csökkent.

Az úgynevezett önkéntes elterelések száma nő, és itt jelentkeznek leginkább, a két esetben bemutatottakon túl is, a problémák. Ilyen visszatérő anomália az, hogy a rendőrhatóság az „önkéntes” elterelésre irányított személyt nem szereli fel olyan dokumentációval, amelyből kiderül, hol, mikor és milyen cselekmény történt. Márpedig ezen információk az elterelési kérdőív kitöltéséhez - amely az eltereléssel kapcsolatos, anonimizált jelentés része - szükséges. A hatóság ez irányú pótlási kérésekre nem reagál túlságosan együttmüködően.

\section{Összefoglalás, következtetések és javaslatok}

Tetszik vagy sem, az elterelés egy folyamat, amely egy rendőri intézkedés elkezdésétől a befejezett elterelésről szóló igazolás elfogadásáig, az elterelt személy büntetőjogi felelősségre vonástól való mentesítéséig tart. Ez többszereplős eseménysor, ahol nem csupán a folyamatban résztvevők, hanem a társadalmi alrendszerek is változnak. Az elterelés jogi fogalom, mert nem orvosi kategóriák, hanem a Btk. paragrafusai által megkövetelt feltételek fennállása vagy azok hiánya mentén - függetlenül az elkövető egyén addiktológiai státuszától - határozza meg a jogszabály az elterelés alkalmazhatóságát. E tekintetben hasonlóságot mutat a beszámítási képességgel. A jogi és az egészségügyi paradigma eltér, de ezek harmóniájának kialakítása az elterelés eredményessége szempontjából fontos lenne. A büntetőjog fontos alapelvei, az önsértő magatartás kriminalizálásától való tartózkodás elve, illetve a büntetőjog végső eszköz jellege. 
(Lévay, 2006) A pszichoaktív szerhasználatot annak egészségkárosító hatása miatt önsértő magatartásként is felfoghatjuk és így a büntetés helyett elterelés elve a cselekmény egyfajta dekriminalizálása. Az elterelés tehát egy újfajta jogi gondolkodás- és megoldásmód, egy reális kompromisszum, amely révén lehetővé válik, hogy a droghasználó a büntetőeljárás alternatívájaként féléves ellátásban részesülve mentesüljön cselekedete büntetőjogi következményeitől. A társadalmi szempontból is sikeres eltereléshez tisztázni kellene az eredményesség fogalmát. A világos célmeghatározás hiánya bizonytalanná teszi az ellátórendszer müködését. A célnak világosnak kell lennie mind az ellátók, mind az ellátást igénybe vevők számára. Egy felmérés szerint az intézményvezetők az egészségügyi ellátás keretében végzett elterelés (kábítószer-függőséget gyógyító kezelés és kábítószer-használatot kezelő más ellátás) esetében a drogfogyasztás csökkentését/megszünését, valamint a reintegrációt/reszocializációt tartották a legfontosabb eredményességi kritériumnak, míg az ellátást közvetlenül végzők az absztinencia elérését fontosnak tartották ugyan, de a klienseikkel a bizalmi kapcsolat megteremtését ennél lényegesebbnek ítélték. (Vitrai és tsai., 2010) Ennek megfelelően a prevenciós aktivitásnak a személyiség fejlesztésére, a családi konfliktusok csökkentésére, megfelelő kontroll kialakítására és pozitív kapcsolatok kiépítésére, a munka és egyéb teljesítmények, eredmények elismerésére és jutalmazására, valamint az aktivitás kifejtés ösztönzésére kell irányulnia, és a kémiai szerek használatának csökkentése, megszüntetése (absztinencia), és a drogos kapcsolatok felszámolása mellett az esetleges pszichiátriai betegség megfelelő kezelését is elő kell segítenie. (Lamberti, 2007) Ezek a beavatkozások mind az egyéni, mind pedig a rendszerben rejlő kockázati tényezők hatását csökkentik, és ezáltal elősegítik a kezelésben maradást, így szakítva meg az ördögi kört.

Kritikaként merül fel, hogy a szakemberek az eredményes elterelés kritériumait nagyon széles skálán értelmezték. (Vitrai és tsai., 2010) Ugyanakkor az is felmerül, hogy után követéses vizsgálatok hiányában pontosan miként is ítélhető meg az elterelés hatékonysága és sikeressége? Vannak országok, ahol speciális bíróságok (Mental Health Courts, Drug Courts) foglalkoznak az elmebetegekkel, illetve a kábítószerfüggőkkel. (Birmingham, 2001; McNiel és tsai., 2007) Lehetséges, hogy Magyarországon is ebbe az irányba kellene elmozdulnia a jogalkotásnak és -alkalmazásnak? Ez a kérdés különösen indokoltnak tünik annak fényében, hogy a jogalkalmazók sem ismerik az általuk alkalmazandó jogi lehetőségeket. (Ritter, 2003) Az elterelés egy jogi procedúra, annak elindításához véleményünk szerint világos jogi helyzetre, hatósági határozatra lenne szükség. Ennek érdekében jogszabályalkotásra van szükség. A modern pszichiátria egyik törekvése, hogy a mentális rendellenességekben és az elmebetegségekben szenvedő bűnelkövetőket a forenzikus rendszer felől minél inkább az egészségügyi ellátás irányába eltérítse. (Birmingham, 2001) Lényegében ebbe a vonulatba illeszkedik a büntetés helyett kezelés elve is. Összefoglalva, bemutatásra került, hogy az elterelésre kötelezettek motivációja csekély, így az a sikeres elterelés inherens akadálya. Tehát ebböl a szempontból nem közömbös, hogy a hatósági eljárás milyen reakciókat vált ki a kliensből.

\section{Felhasznált irodalom}

Birmingham, L. (2001): Diversion from custody. Advances in Psychiatric Treatment, 7, 198-207. Csorba J. (2000): A drogfogyasztók elterelésének klinikai vonatkozásai. In: Németh A. - Gerevich J. (szerk.): Addikciók. Budapest: Medicina Kiadó, 73-88.

Kalapos M. P. (2011): Büntetés helyett kezelés. Az elterelés intézménye. Psychiatria Hungarica, 26, 393-414.

Kalapos M. P. (2016): Bevezetés az addiktológiába. Budapest: Medicina Kiadó

Lamberti, J. S. (2007): Understanding and preventing criminal recidivism among adults with psychotic disorders. Psychiatric Services, 58, 773-781.

Lévay M. (2006): Büntetés helyett kezelés: Racionális és szükségszerü kompromisszum a kábitószer-problémával kapcsolatos kriminálpolitikában. Addiktológia, 5, 342-358

Medveczky R. (2009): Egy jogintézmény jelentése - pártfogói narrativák a csekély mennyiségü kábitószerrel visszaélö fiatalok eltereléséröl. Addiktológia, 8, 5-62.

McNiel, D. E. - Binder, R. L. (2007): Effectiveness of a Mental Health Court in reducing criminal recidivism and violence. American Journal of Psychiatry, 164, 1395-1403.

Melles K. - Márványkövi F. - Lencse M. (2008): A büntetés helyett kezelés elvének érvényesülése egy drogambulancia betegeinek vizsgálata alapján. Orvosi Hetilap, 149, 601-607.

Rácz J. (2005): Az elterelésröl. Szakirodalmi összegzés. Addiktológia, 4, 89-102.

Ritter I. (2003): (T)örvény/A kábitószerrel való visszaélés büntetöjogi megitélésének hatásvizsgálata - 1999. március 1. után. Budapest: L’Harmattan Kiadó

Vitrai J. - Busa Cs. - Füzesi Zs. - Kesztyüs M. - Szilágyi J. -Tistyán L. (2010): Tanulmány az „Elterelés hatásosságának vizsgálata” címü tanulmány eredményeibőll. Budapest: Fact Alkalmazott Társadalomtudományi Kutatások Intézete 